УДК 629.7.015.А.028.2

Забаита В. Ф.

AT «Український науково-дослідний інститут авіаційної технології. Україна, м. Київ

\title{
ДО ПИТАННЯ ПРО ПЕРСПЕКТИВНІ З' СДНАННЯ АВІАКОНСТРУКЦІЙ ІЗ ПОЛІМЕРНИХ КОМПОЗИЦІЙНИХ МАТЕРІАЛІВ
}

В статті пропонується один із способів з'єднання елементів конструкиій планера літального апарату із полімерних композиційних матеріалів (переважно вуглепластиків). Проаналізовані аналоги конструктивно-технологічних особливостей кріпильних систем, призначених для з'єднання композитних елементів конструкцій, утворюемих при наявності тільки однобічного підходу в зону поставлення кріплення, а саме витяжна заклепка (ВЗ). В статті вона складається з корпуса, сер- 
дечника, ииліндричної втулки, а також має контрувальну ділянку (запірне кільце відсутнє). Вибір матеріалів заклепки здійснений з урахуванням щільності струму корозіі. Запропонована формалізована конструктивно-технологічна схема логічної структури цієї витяжної заклепки (ВЗ-схема). [dx.doi.org/10.29010/88.5]

Ключові слова: композит; вуглепластик; витяжна заклепка; корпус; сердечник; деформуєма втулка; контрувальна ділянка; рифлена поверхня; заклепочне з'єднання; формалізована ВЗ-схема.

\section{Вступ}

Для з'єднання різних елементів конструкцій планера літального апарата (ЛА), виконаних із полімерних композиційних матеріалів (ПКМ), на сьогодні застосовуються різні види стрижневих заклепок (матеріали - Д18, В95, Д94) та спеціальних заклепок, що забезпечують однобічний доступ до заклепочного шву (матеріали - 30ГХСА, нержавіючі сталі, алюмінієві титанові та монелеві сплави [11, 12, 16, 19, 49 та ін.] ). Серед них широке поширення набули витяжні заклепки (В3), тобто заклепки з витяжним сердечником. Цей об'єкт в статті несе логічний наголос і в основному визначає iï зміст. Так, наприклад в [12] підкреслюється, що із секторів ринку кріпильних систем 3 найбільш інтенсивним розвитком, є саме кріплення, які ставляться при наявності тільки однобічного підходу в зону складання (кріпильні системи однобічного поставлення - КСОП).

При цьому підкреслюється, що технологія виконання вищенаведених з'єднань в таких зонах відноситься, як правило до категорії «особливо відповідальних технологічних процесів». В річищі цього напрямку, матеріали статті саме відносяться до В3 поширеного комбінованого варіанту для однобічної клепки елементів конструкції із листових матеріалів, найпоширеніше авіабудівельного призначення на основі ПКМ i, найпоширеніше, з вуглепластиків (ВП) [1-3]. При цьому з виділенням серед інших типів тонкостінних пакетів (деталей) «ВП+ВП». Наприклад, на рис. 1 це пакет 3 позначенням $(1+14), 3$ яким взаємодіє система КСОП. Тут завжди враховується можливість прояву контактної та атмосферної корозії заклепки [5-10].

Відомо, що ВП характеризуються низькою міцністю на зім'яття, малою поверхневою твердістю та, водночас, високою катодною активністю з більшістю металів, що веде до корозійного руйнування заклепок [4, 49 та ін.]. ВIАМ (РФ), ВВС та ВМС США встановили, що найбільша небезпека корозії виникає після свердління отворів під кріпильні деталі в вуглепластикових (графітоепоксидних) панелях.

Свердління оголює кінці вуглеволокон, які контактують з кріпильними деталями та втулками. $\mathrm{C}$ повідомлення про значну корозію алюмінієвих сплавів на зовнішній поверхні фюзеляжу винищу- вача F-22 (стики з вуглепластиком). В результаті досліджень, проведених лабораторією авіаційних матеріалів США, сполучення металевих сплавів 3 ВП по щільності струму гальванічної пари $\left(j, \mathrm{MA} / \mathrm{cm}^{2}\right)$ розділені на прийнятні $(j<5$, табл. 1$)$, критичні $(5 \leq j \leq 15)$ та неприйнятні $(j>15)$ [ 4 ].

При виборі КСОП в процесі проектування з'єднань звертається увага, передусім, на такі фактори: умови експлуатації, максимальні навантаження; характеристики матеріалів та товщина з'єднуваних деталей; матеріали металевих деталей заклепки, в тому числі в комбінованих варіантах, а також сумісність їх з матеріалами з'єднуваних пакетів (деталей), якість, надійність і вага заклепки та ін.

При цьому у В3 загального (міжгалузевого) призначення серед металевих сплавів (МС) виділені:

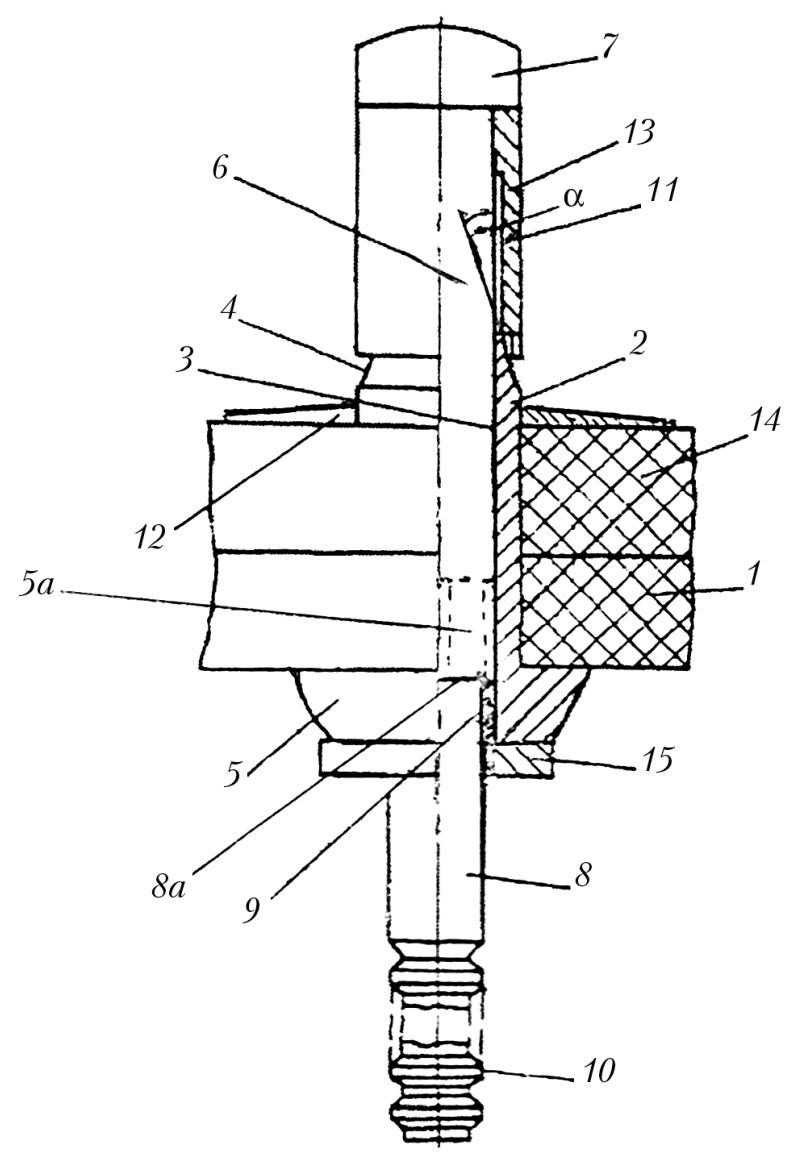

Рис. 1. Загальний вигляд витяжної заклепки (вихідне положення) 
Допустимі сполучення конструкційних металевих матеріалів з графітоепоксидними композиційними матеріалами, оцінка по щільності струму контактних пар

\begin{tabular}{|c|c|c|}
\hline $\begin{array}{l}\text { № } \\
\text { п/ா }\end{array}$ & $\begin{array}{c}\text { Матеріали контактуючі з } \\
\text { вуглепластиком }\end{array}$ & 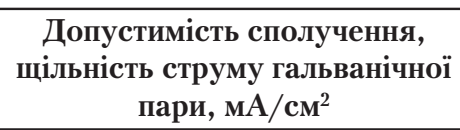 \\
\hline 1 & Ti-6Al-4V (BiAM BT6) & \multirow{9}{*}{$\begin{array}{c}\text { Прийнятно: } \\
\quad J<5\end{array}$} \\
\hline 2 & $\mathrm{Ti}-6 \mathrm{Al}-2 \mathrm{Sn}-4 \mathrm{Zr}-2 \mathrm{Mo}$ & \\
\hline 3 & $\begin{array}{c}\text { Рене-41 } \\
\left(\mathrm{Ni}-19 \mathrm{C}_{\Gamma}-11 \mathrm{Co}-10-\mathrm{Mo}-3 \mathrm{Ti}-1,5 \mathrm{Al}\right)\end{array}$ & \\
\hline 4 & $\begin{array}{c}\text { Інконель } \mathrm{X} \\
(\mathrm{Ni}-15 \mathrm{Cr}-7 \mathrm{Fe}-2,5 \mathrm{Ti}-1,0 \mathrm{Co}-0,7 \mathrm{Al})\end{array}$ & \\
\hline 5 & Інконель $(\mathrm{Ni}-15 \mathrm{Cr}-7 \mathrm{Fe})$ & \\
\hline 6 & $\begin{array}{c}\text { AFC-77 } \\
(\mathrm{Fe}-14,5 \mathrm{Cr}-13 \mathrm{Co}-5 \mathrm{Mo}-0,4 \mathrm{~V}-0,15 \mathrm{C})\end{array}$ & \\
\hline 7 & PH17-7 (Fe-17Cr-7Ni-1,2Al-0,07C) & \\
\hline 8 & Корозійностійкі сталі 301 і 304 & \\
\hline 9 & $\mathrm{Cu}-1 \mathrm{Be}$ & \\
\hline
\end{tabular}

Другий - рівень КТР по забезпеченню належної надійності стопоріння сердечника ВЗ при їі експлуатації.

В статті також зроблено спробу дослідити питання формалізації (графічне представлення) в напрямку заклепочних з'єднань на прикладі складання формалізованої схеми витяжної В3 (склад об’єктів та їх взаємодія).

Як відомо [49-52], формалізована схема, як об'єкт моделювання, наприклад, процесу 3 відображенням його суттєвих властивостей, $€$ проміжною стадією між змістовним описом та математичною моделлю. В даній статті конструктивно-технологічного характеру нема необхідності придержуваалюмінієві (Al) та титанові (Тi) сплави, а також вуглецеві (St) та леговані корозійностійкі сталі (Sta).

Говорячи про з'єднання пакетів типу «МC+MC», то найпоширеніше в будівельній галузі, промисловості, в наземних транспортних засобах та інше представлені ВЗ, які складаються з двох основних деталей: корпусу (тіла) заклепки та витяжного сердечника (стрижня) з наступною комбінацією матеріалів виготовлення: $\mathrm{Al} / \mathrm{Al}, \mathrm{Al} / \mathrm{St}, \mathrm{Al} / \mathrm{Sta}, \mathrm{Sta} / \mathrm{Sta}$. Тут і далі в позначеннях на першому місці стоїть матеріал корпусу, а на другому - позначення сердечника заклепки $[18,49]$. Серед вказаних типів найбільше розповсюдження через низьку вартість та легкість клепання, основне місце займають заклепки в варіанті $\mathrm{Al} / \mathrm{St}$, де європейськими виробниками широко застосовується сплав $\mathrm{Al} \mathrm{Mg} \mathrm{3,5 \%} \mathrm{та} \mathrm{вуглецева} \mathrm{сталь} \mathrm{з} \mathrm{цинковим}$ покриттям товщиною в середньому 7 мкм [18, 49].

Вимоги до вказаних двоскладових ВЗ із алюмінієвих сплавів і сталевого сердечника, наприклад, приведені в [18, 49].

В статті зроблений наголос саме на авіаційній В3. Проведений укрупнений аналіз опублікованої інформації i, спираючись на нього, представлений новий варіант ВЗ. Ці матеріали при систематизації доволі умовно з врахуванням двох факторів поділені на чотири групи: ближні аналоги (п. 2.1), дальні аналоги (п. 2.2), прототип (п. 2.3) та запропонований варіант В3 (п. 3).

При цьому перший фактор, це конструктивнотехнологічний рівень забезпечення пристосованості КСОП до з'єднання композиційних (переважно вуглепластик) листових елементів конструкції, в тому числі малих товшин (рівень адаптування під конкретну практичну задачу). тись повної (жорсткої) формалізації. Достатньо подати iï на першому кроці в схематичному (графічна форма), в доволі спрощено-узагальненому вигляді з можливістю подальшої деталізації. Тобто, як правило, на початку прибігають до спрощення та огрублення поставленої задачі.

На рис. 9 представлена така укрупнена багаторівнева складова схема взаємодії елементів ВЗ при клепці листових ПКМ.

\section{1. Ціль та комплекс задач дослідження}

В основу запропонованої удосконаленої концептуальної схеми поставлена ціль підвищення надійності, технологічності В3, можливості зменшення габаритів та ваги заклепки, та розширення номенклатури з'єднувальних пакетів, в тому числі, на основі тонколистових вуглепластиків.

Для досягення поставленої мети вирішується комплекс задач, серед них:

1. Провести порівняльно-узагальнений конструктивно-технологічний аналіз уживаних концепцій ВЗ для з'єднання листових ПКМ, передусім, з вуглепластиків.

2. Представити удосконалені КТР по таким напрямкам:

- зменшення навантаження навколокорпусного краю отвору пакета при утворенні замикаючої головки;

- збільшення опорної поверхні замикаючої головки;

- застосувати нову схему стопоріння сердечника на основі принципу з'єднання рифлених поверхонь; - підвищити рівень багатофункціональності В3; 
- визначити основні моменти при виборі першорядного матеріалу для корпуса В3;

- спрощення технологій утворення заклепочного з'єднання.

3. Скласти формалізовану В3-схему.

\section{2. Авіаційні витяжні заклепки (концептуальні аспекти)}

\section{1. Початковий етап концептуального розвитку} В3 (дальні аналоги)

В3, як дальні аналоги запропонованої концепції В3, для застосування в авіабудуванні, наведені в $[17,19,49]$ та ОСТ 1.11246. Під дальніми аналогами тут розуміються двоскладові В3, які мають більш прості конструктивно-технологічні схеми (КТС) та конструктивно-технологічні рішення (КТР), ніж викладені в п. 2.2 ближні аналоги [12, $19,25,49]$ та В3, вибрані за прототип [26]. Найперше, в дальніх аналогах практично, крім натягу, відсутні спеціальні (особливі) засоби та способи фіксації проти можливого виповзання (випадання) сердечника із корпуса при значних експлуатаційних навантаженнях. 3 огляду на цю виключну обставину та виходячи з неї, як показано нижче, в області ефективного застосування В3, дальні аналоги віднесені саме до простих В3.

Цей поділ також пов'язаний з основним призначенням запропонованої (п. 3) ${ }^{1}$ моделі КСОП i, передусім, в авіабудівельній царині, а саме - високотехнологічного виформування заклепочного з'єднання складальних одиниць (пакетів, деталей) із ПКМ і, найперше, з’єднання «ВП + ВП» із підвищенням його якості та надійності, в тому числі за рахунок формування замикаючої головки (ЗМГ), збільшення міцності зчеплення сердечника з корпусом В3, а також з урахуванням факторів контактної та атмосферної корозії.

У зв'язку з цим, до дальніх аналогів належать B3, задіяних у з'єднаннях «MC + МC», а ближні аналоги пов'язані з В3, які можуть бути використані у з'єднаннях «MC + ПКМ» i, нарешті, прототип, вочевидь, пов'язаний саме зі з'єднанням «ПКМ + ПКМ» i, найперше, «ВП + ВП». При цьому, в з'єднанні «МС + ПКМ» закладна головка установлюється виключно зі сторони ПКМ.

У дальньому аналогу [17], йдеться про з'єднання елементів конструкцій із листового алюмінієвого сплаву $(\mathrm{Al} / \mathrm{Al})$. Ці заклепки містять циліндричний корпус з закладною головкою (потайною чи напівкруглою) і центральним отвором, в якому 3 визначеним натягом поміщений сердечник з головкою (кут конусу $120^{\circ}$ ) з одного кінця і технологіч- ним хвостовиком з обривною шийкою 3 іншого. Корпус В3 виконаний із сплаву Д18П, а сердечник із сплаву Д16П. При цьому, як розповсюджений приклад, застосування матеріалів двоскладових В3 в з'єднанні «МC + MC», низьколегований сплав Д18П (корпус) є менш міцним, але, як головне, водночас, і більш пластичним, ніж сплав Д16П (сердечник). Вказана пластичність згідно КТС та КТР необхідна, по-перше, для якісного формоутворення замикаючої головки при малих зусиллях, а, подруге, для створення достатнього натягу, який може досягати $~ 5 \%$, оскільки сердечник в подібних конструкціях фіксується в корпусі лише наявним радіальним натягом.

Таким чином, у цій КТС, сердечник розвальцьовуючий верхню частину циліндричного корпуса та роздаючий його тіло в процесі натягу, являє собою, подібно пуансону в листовій штамповці, основний деформуючий елемент (технологічний інструмент).

Але описані КТС та КТР майже унеможливлюють іх застосування у випадку з'єднання пакетів «ВП + ВП». По-перше, розвальцювання корпуса під замикаючу головку впродовж всього одноперехідного процесу з практично повним опиранням на вразливу поверхню вуглепластика може призвести навіть до розкришування його навколокорпусної зони. Тому через незначну пластичність ВП, тут найбільш прийнятне застосування, наприклад, методів так званої малодеформаційної клепки, наприклад, зі збільшенням опорної площі, за рахунок підкладних елементів та інше.

По-друге, необхідно виходити з того факту, що критичний натяг ВЗ в заклепочних з'єднання для вуглепластиків 3 врахуванням критеріїв міцності композитів, близький до 1\% [16].

В заклепочних з'єднаннях ефект перевищення критичного натягу для смол слід розглядати як незворотні зсуви волокнистого каркасу, а не його руйнування, оскільки, по-перше, переплетіння ниток основи та утка визначає деякий запас деформації i, по-друге, ці деформації виключно визначаються деформаційністю зв'язуючого [16]. Тому радіальний натяг на рівні 5\% і пов'язана 3 цим величина випинання циліндричної частини корпусу В3 $є$ недопустимою в композитних конструкціях через можливе небезпечне деформування вуглепластика в кільцевій прилягаючій зоні отвору.

Розширення в порівнянні 3 [17], номенклатури конструкційних матеріалів складальних одиниць та В3 в з'єднаннях «МС + МC», приведені в табл. 2 [19]. Це з відповідними захисними покриттями алюмінієві та титанові сплави, а також корозійностійкі сталі. При цьому, в нормативному документі

\footnotetext{
${ }^{1}$ Запропановану ВЗ будемо вважати (називати) високоадаптнивною ВЗ, передусім, для умов з’єднання тонкостінних вуглепластикових елементів конструкцій ЛА та ін.
} 
Призначення покриттів за ГОСТ 9.306-85

\begin{tabular}{|c|c|c|}
\hline \multirow{2}{*}{ Матеріал } & \multicolumn{2}{|c|}{ Вид покриття за ГОСТ 9.306-85 } \\
\cline { 2 - 3 } & Найменування & Позначення \\
\hline \multirow{2}{*}{ Сталі корозійно-стійкі } & $\begin{array}{c}\text { Окисне, що отримується способом } \\
\text { хімічного пасивування }\end{array}$ & Хім.Пас \\
\hline \multirow{2}{*}{ Алюмінієві сплави } & Без покриття & Ан.Окс.нхр \\
\cline { 2 - 3 } & $\begin{array}{c}\text { Анодно-окисне, наповнене, } \\
\text { у розчині хроматів }\end{array}$ & Ан.Окс.хром \\
\cline { 2 - 3 } & $\begin{array}{c}\text { Анодно-окисне, що отримується } \\
\text { в розчині хромового ангідриду }\end{array}$ & Ан.Окс. \\
\hline \multirow{2}{*}{ Титанові сплави } & $\begin{array}{c}\text { Анодно-окисне, що отримується } \\
\text { імпульсним методом, не кольорове }\end{array}$ & А \\
\hline
\end{tabular}

[19] обумовлюється, що зі сторони замикаючої головки має бути розташований матеріал 3 міцністю $\sigma_{\text {в }}$ не менше 294 МПа для заклепок із алюмінієвого сплаву і не менше 540 МПа для заклепок із корозійностійкої сталі. Водночас, для уникнення викривлення та затяжок тонколистових конструкцій, що виникають в зоні отворів під заклепками під дією радіальних натягів, товщина деталі (складальної одиниці) під замикаючою головкою повинна бути не менше 0,5 мм, а в разі, застосування заклепок із корозійностійкої сталі, ця товщина деталі повинна бути не менше 1 мм, якщо матеріал, з якого

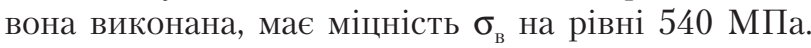
Здійснення вказаних обумовлень сприяє збільшенню технічного ресурсу з'єднань.

Особливо важлива реалізація вказаних застережень в з'єднаннях «ВП +ВП», враховуючи уразливість поверхні, рівень тріщиностійкості та деформативності, а також міцності на зсув вуглепластика та інше.

Вище було зазначено, що близькі аналоги та прототип між собою відрізняються рівнем пристосованісті (адаптованості) В3 до клепки при наявності в з'єднанні композитних складальних одиниць, найпоширеніше, з вуглепластиків, а, по-друге, в конструктивно-технологічних рішеннях В3 наявні спеціальні заходи та способи стопоріння сердечників. Для наглядного представлення наявності в ВЗ стопоріння може бути використане для прикладу таке умовне позначення: $\mathrm{Al} \psi \mathrm{Ti}$, Ti $\psi \mathrm{Ti}$, Sta $\psi \mathrm{Ti}$ та інші.

В залежності від конструкції і методу поставлення (обертання чи прямолінійний рух) КСОП можна розділити на два основні види ( різьбові та безрізьбові) $[12,49]$. Різьбові В3 містять корпус з внутрішньою різьбою, гвинт (сердечник) та деформуємий елемент [12, 21, 23, 49].

Важливим параметром, що визначає довговічність такого скріплення деталей є зовнішній діаметр різьбової ВЗ. Чим більше значення цього параметру, тим більше надійним буде одержане з'єднання, а значить, тим більше навантаження може витримувати конструкція в період експлуатації. У випадку поставлення різьбового ВЗ ручним інструментом, можуть виникнути труднощі (значна протидія), а товщина стінок, водночас, впливає на зручність роботи [49].

Недоліком цих заклепок є, по-перше, трудність нарізання внутрішньої різьби корпусів, які по умовам допустимого контакту з ВП, можуть виконуватися із важкооброблюємих, наприклад, титанових сплавів.

По-друге, відомо [12, 49 та інше], що розкручування (самовідгвинчування) є однією 3 основних причин ослаблення та втрати початкової фіксації різьбових з'єднань внаслідок дії перемінних і/чи вібраційних навантаженнях. При цьому в [12], на основі проведених робіт зазначено, що методи стопоріння таких з'єднань, які, наприклад, викладені в нормативному документі [20], не можна визнати ефективними.

\section{2. Ближні аналоги.}

В [12, табл. 1] представлені вибіркові дані, що характеризують КСОП основних світових виробників для авіаційних конструкцій (5 фірм-виробників), де рекомендуються, як різьбові, так і безрізьбові ВЗ. При цьому згідно [12], в номенклатурі продукції, що випускається, переважають КСОП замикаючий елемент яких сформовується внаслідок деформування фрагмента корпуса чи кільця, в конструкціях яких відсутня різьба.

Замість різьбових з'єднань в [12] рекомендується використовувати в конструкціях літаків (гвинтокрилів) витяжні заклепки, при установлюванні яких учиняється роздача корпуса і застосований запірний сердечник, насамперед, за індексом NAS1919 компанії ASFR. Конструкція В3 складається [12, рис. 2] із корпуса з закладною головкою, 
сердечника з технологічним хвостовиком, запираючого кільця та установлюючої шайби.

Матеріал корпуса В3 - корозійностійка сталь, монелевий або алюмінієвий сплави. Матеріали сердечника та з'єднувальних пакетів при цьому не уточнюються. Нижче скорочено представлені етапи сформування замикаючої головки ВЗ аналога [12, рис. 3]. В ньому використовується відомий в теорії та з практики ефект локальної втрати усталеності (рос. устойчивости) в тонкостінному циліндрі (корпус В3) при його осьовому стиску. Тут, в загальному, має місце короткохвильова форма випинання (рос. выпучивания), а саме локального кільцевого зморщування стінки циліндра в складку (гофр) $з$ прикінцевим сплющенням ${ }^{2}$ цієї складки.

Повна, або ж пружно-пластичне деформування в локальній зоні корпуса після уставлення його в отвори з'єднувального пакета, полягає в наступному [12, рис. 3].

При стиску головкою сердечника торця циліндричної частини корпуса, останній при осадці на границі з поверхнею пакета втрачає усталеність в формі кільцевої складки, яка, опираючись на вказану поверхню, в подальшому сплющується з утворенням доволі звуженого за площиною кільцевого бурта.

Останній, будучи сформованим на поверхні пакета, використовується для стискання його в технологічному процесі уставлення В3.

В контексті вищевикладеного і, насамперед, відносно методу деформування циліндричної частини корпуса, з утворенням замикаючої головки, попередньо напрошується логічний висновок, що мова саме йде більш про з'єднання «МC+MC» (можливо $\mathrm{i} \ll \mathrm{MC}+$ ПКМ»).

Вказаний висновок грунтується на тому, що в цій формоутворюючій операції листової штамповки силова осадка жорсткого корпуса 3 опиранням на вуглепластиковий пакет може понадміру пошкодити i, навіть, зруйнувати навколокорпусний край отвору пакета, і тим суттєво послабити з'єднання [13-15].

Відомо, як аналог ВЗ із запірним сердечником при застосуванні в авіабудуванні з віднесенням її ближче до з'єднань «МС+ПКМ» (а не «ПКМ+ПКМ»), а саме через КТР утворення замикаючої головки подібно вищевказаному в [17], тобто з розвальцюванням верхньої частини циліндричного корпуса з опиранням при цьому на поверхню В3 за рахунок силової дії рухливого сердечника [25, фіг. 1]. Однак в цьому патенті не зазначені такі атрибути з'єднань, як типорозмірний ряд В3, про який йде мова; матеріали сердечника та корпуса, а також матеріали з'єднувального пакету.

Ближній аналог[25] відрізняється від дальшого [17] тим, що зі сторони хвостовика 3 обривною шийкою на робочій поверхні установлювального 3 натягом сердечника, а саме, в кільцевій ступінча- стій проточці розташована контрувальна ділянка 3 косим рифленням на поверхні.

При цьому висота $h$, кута між сусідніми зубцями $a$ і залежність кроку $P$ від діаметру $D$ і ширини $B$ рифленої поверхні приведені в [29]. Тут висота рифлення $h$ для сталі складає $0,25 \ldots 0,7$ Р, а для кольорових металів та сплавів 0,25...0,5 Р. Кут $а$ для рифлень по сталі $70^{\circ}$, і $90^{\circ}$ для кольорових металів та сплавів [рис. 6].

Як відомо [29, 30, 49], рифлення взагалі достатньо часто використовується в таких випадках:

- запресування елементів кріплення в нерозбірних з'єднаннях;

- забезпечення локалізації деформації в момент утворення деталі однобічного поставлення;

- забезпечення рівномірної деформації;

- самостопоріння частин учасників з'єднання;

- зручність та збільшення швидкості проведення складальних робіт.

Зовнішні діаметри контрувальної ділянки менше діаметра робочої частини на $0,1-0,2$ мм, а кут між направляючими зубців рифлення з віссю сердечника складає 5-10. При цьому корпус має в зоні закладної головки відповідний для з'єднання гладкий внутрішній уступ. Виконання сердечника 3 контрувальною ділянкою з рифленням і отвору в корпусі ступінчастим, забезпечує надійне зчеплення сердечника з корпусом. Це відбувається внаслідок того, що при втягуванні сердечника в корпус рифлення проникає у внутрішній уступ металевого корпуса за рахунок різниці діаметра уступа під контрувальну ділянку і зовнішнього діаметра рифлення на сердечнику.

Рифлення збільшує площу контакту взаємодіючих поверхонь сердечника та корпуса і впливає на міцність їх зчеплення. Різниця в $0,1 \ldots 0,2$ мм, тобто власна висота рифлення $h$, згідно [29], є найбільш оптимальною величиною, яка забезпечує проникнення зубців рифлення в метал корпуса.

За рахунок нахилу лінії зубців рифлення 5-10 (i рівчачків між ними) досягається необхідність сердечника здійснювати обертовий рух у випадку видавлювання його при прикладанні перевищуючих осьових навантажень. Якщо кут нахилу зубців складає менш ніж $5^{\circ}$, то зменшаться осьові навантаження тертя від рифлення на закрут сердечника від кута нахилу зубців, що приведе до зниження навантажень видавлювання сердечника. При куті нахилу зубців більшим $10^{\circ}$, збільшаться осьові навантаження тертя, що впливає на якісне поставлення ВЗ.

Виконання контруючої ділянки 3 косим рифленням збільшує надійність заклепочного з'єднання, перешкоджає видавленню сердечника при виникненні осьового навантаження. Експериментальні дослідження [25] показують, що запропонована В3 витри-

\footnotetext{
${ }^{2}$ Випробовуванням на сплющення визначають здатність металу деформуватись при сплющенні.
} 
мує навантаження видавлювання в 4,2 рази більше в порівнянні з раніш представленою роботою [17].

3 короткого опису змісту патенту [25] напрошується висновок, що матеріал корпуса ВЗ більш пластичний, та менш твердий, чим матеріал сердечника, оскільки корпус підлягає розбортуванню в своїй верхній циліндричній частині, протяжці сердечника $з$ натягом по довжині та нанесенню їм рифлення в зоні закладної головки корпуса.

Водночас, сердечник повинен бути і більш міцним не тільки через зазначене різнобічне деформування корпуса, але із-за наявності внутрішньої контрувальної ділянки. Справа, по-перше, в тому, що зовнішній діаметр цієї ділянки на 0,1...0,2 мм менший від номінального діаметра сердечника, а, по-друге, висота зубців рифлення, в свою чергу, складає згідно [25] 0,1...0,2 мм.

Таким чином, номінальний діаметр сердечника зменшується на рівні 0,5 мм, при цьому без прив'язки до конкретного діаметра ВЗ. Однак, враховуючи матеріали [25] 3 деяким приведеними параметрами рифлення на основі нормативного документа [29] можна зробити першопочатковий висновок, що мова може йти про діаметр В3 саме 4 мм. Тоді для цього випадку, наприклад, в комбінованій заклепці «алюміній-сталь» номінальний діаметр гладкої частини сердечника згідно [18] складає 2,35 мм, а з урахуванням зниження його до 1,85 мм, площа живого перерізу такого сердечника буде на рівні 60\% від номінального значення. Це потребує додаткового підсилення сердечника. Внаслідок цього недоліка практично неможливо взагалі отримати експлуатаційно придатні заклепки менших діаметрів, наприклад, 3,2 чи 3,0 мм, хоча кріплення саме малих діаметрів рекомендовані при з'єднанні композитних деталей [26]. В високоадиптивній В3 (п. 3) цей недолік усунутий тим, що ділянка рифлення, як інструмент накатування, розташована на відміну від аналога, не на сердечнику, а на корпусі ВЗ в зоні закладної головки, що дозволяє більш ефективне використання матеріалів 3 позицій пристосування до з'єднань «ВП + ВП». При цьому довжина ділянки контрування визначається експериментально.

\section{3. Прототип.}

Найбільш близьким до представленої ВЗ за технічним призначенням та результатом, що досягається є запропонована в [26] на основі патентів [22 та ін.] витяжна заклепка з запірним сердечником для однобічної клепки листових композитних авіаконструкцій [26, рис. 1]. Вона містить металевий пустотілий корпус 3 закладною головкою та циліндричною частиною. Остання в торці має зовнішню монтажно-західну фаску у вигляді конічної та увігнутої формуючих ділянок. В осьовому отворі корпуса установлений з натягом сердечник з головкою та робочою частиною з одного кінця та технологічним хвостовиком з обривною шийкою в іншому кінці. На робочій частині сердечника, по-перше, має місце кільцева виточка зі стопорним кільцем, а, по-друге, вставлена циліндрична деформуєма втулка з розміщенням між головкою сердечника та заходом на фаску циліндричної частини корпуса. В ході сердечника втулка деформується шляхом роздачі ${ }^{3}$, утворюючи з головкою сердечника замикаючу головку В3. В прототипі застосовується відома схема запирання сердечника з використанням стопорного кільця [13, 25, 49]. Тут також вказується на експериментальне підтвердження КТР, але відсутні типорозміри та матеріали запропонованої ВЗ. До недоліків прототипу слід віднести багатодетальність та складність конструкції, суттєве зменшення площі живого перерізу сердечника в місцях розташування виточки. До зауважень слід віднести також неповне обгрунтування деяких висновків. Так, відомо [40, 49], що в листовій штамповці при роздачі заготовок одних і тих же розмірів деформаційне зусилля тим більше, чим вище характеристика міцності матеріалу заготовки, ступінь деформаціï, сили контактного тертя, а також на це впливає кут нахилу твірної пуансона $\alpha$ (рис. 1). При цьому, по сумі вказаних характеристик існують оптимальні кути, при яких зусилля роздачі найменше. Для повних або суцільних циліндричних пуансонів оптимальні кути конусності складають 15-20. Ясно, що ці значення повною мірою не є можливими для пустотілих циліндричних пуансонів типу тонкостінного корпуса ВЗ. Тим не менш, за цих обставин, в прототипі зроблений всеосяжний висновок про те, що за всіх умов, незалежно від матеріалів та товщини стінок корпуса, кут конусу $\alpha$ дорівнює 6-10 (рис. 2). Ясно що ВЗ діаметрами в

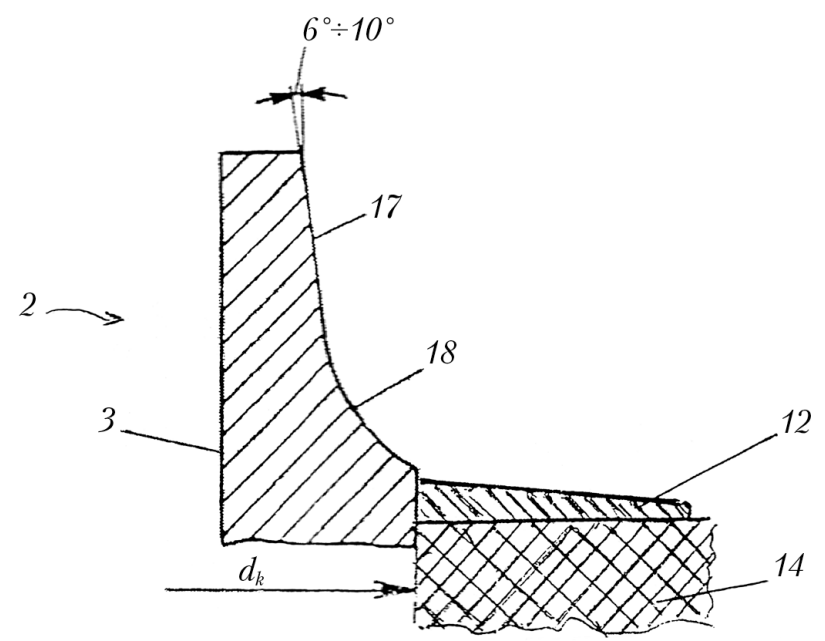

Рис. 2. Верхня формуюча частина корпуса заклепки

\footnotetext{
${ }^{3}$ ГОСТ 8694-75. Метод испытания на раздачу.
} 
інтервалі 3,0-6,4 мм значно відрізняються, а відтак, і граничні значення кутів $\alpha$ будуть неоднакові, в тому числі більш наближеними до оптимальних значень кутів $\alpha$ при діаметрі 6,4 мм. Тому вказані в прототипі значення цих кутів можуть бути прийнятні саме для малих діаметрів ВЗ.

Загальним же недоліком приведених аналогів та прототипу є неврахованість істотних обмежень, що накладають на вибір в них КТР та матеріалів саме внаслідок контактної, атмосферної та загальної корозії складових ВЗ. Тобто тут має місце невизначеність допустимих матеріалів, що є особливо важливим фактором в з'єднаннях типу «ПКМ+ПКМ», виходячи 3 особливостей цих матеріалів. Тому вказані питання потребують модернізації, передусім, у вигляді доцільних КТР.

\section{3. Високоадаптивна витяжна заклепка (удосконалена багатофункціональна система $[26,28])$}

\section{1. Змістовний виклад}

Пропонуєма КСОП являє собою систему з прямолінійно поступальним рухом сердечника. Нові та модернізовані КТР початкового рівня пов'язані в системі з категоріями доцільності, в т.ч. багатофункціональності ${ }^{4}$ достатності (техніко-економічні розрахунки, повнота показників та ін.), а також достовірності (експериментальне підтвердження, в тому числі запозиченого характеру).

В пропонуємій КТР в складі циліндричного пустотілого корпуса, сердечника та деформуємої втулки ${ }^{5}$ (рис. 1) для однобічної клепки елементів конструкцій i, найпоширеніше, в планері транспортних літаків/гвинтокрилів, переважно в з'єднаннях «ПКМ+ПКМ» i, головним чином «ВП+ВП», вирішуються наступні взаємопов'язані задачі:

1. Підвищення рівня багатофункціональності КСОП, в т.ч. розширення номенклатури ВЗ в групуванні кріплень, де застосовується принципово нова схема контрування на основі рифлень для поєднання корпуса з сердечником на визначеній ділянці та прямого методу утворення (деформування) ЗМГ,

2. Підвищення надійності принципової схеми елементів В3 і, найперше, в напрямках підвищення міцності зчеплення сердечника з корпусом та спрощення їх робочої взаємодії при поставлені заклепки в з'єднувальний пакет.

3. Спрощення процесу утворення замикаючої головки з одночасним підвищенням її якості.

4. Забезпечення протидії можливому утворенню та розвитку контактної та атмосферної корозії складальних елементів В3.
5. Поставлені задачі, деталізуючи, вирішуються також тим, що в ВЗ застосовуються високонесучий корпус, i, як обгрунтовано нижче, із титанового сплаву ВТ6, становлячи собою ключовий, багатофункціональний елемент в складі В3, а саме:

- як базовий технологічний елемент при складанні та взаємодії рухливих спряжених деталей В3;

- як технологічний інструмент та чинник в таких двох випадках:

- формування замикаючої головки шляхом роздачі деформуємої втулки (подібно пуансону в листовій штамповці);

- формування рифлень в сердечнику з одночасним утворенням контрувальної ділянки ВЗ.

6. Поставлені задачі, деталізуючи, вирішуються також тим, що в одноперехідній операціі з'єднання пакета при деформуванні втулки, визначені нагальні прийнятні параметри штампуємості (формозмінності) цієї деталі, в тому числі граничні (максимальні) значення коефіцієнта роздачі циліндричної заготовки $K p$, а також як експериментальний параметр, мінімізованого рівня зусилля при іï формуванні та ін. При цьому $K p=D p / D$, де $D p-$ найбільший діаметр деформованої частини втулки, а $D-$ вихідний діаметр циліндричної заготовки. Таким чином, наявність в складі В3 деформуємої втулки дозволяє: зменшити навантаження на навколокорпусний край отвору пакета, збільшити опорну поверхню ЗМГ та зручність її формування.

7. Поставлені задачі за умов доцільності/необхідності і достатності (повноти) та достовірності, вирішуються шляхом комплексного коректного підходу при виборі найбільш прийнятних матеріалів КСОП.

Наостанок, представлені відправні моменти при визначенні першорядного матеріалу корпуса запропонованої В3 в пріоритетній черзі інших матеріалів. Так, з дев'яти, представлених в табл. 1, матеріалів, які мають прийнятні значення струму корозії при контакті з ВП (вихідний показник вибору), чільне місце займають титанові сплави ВТ6.

Водночас, широковідомо $[4,44,49]$ i, як показано нижче, механічну обробку вказаного сплаву, в тому числі протягування внутрішніх пазів, відносять до важких технологічних процесів. Крім цього, ця обробка може привести до пошкоджень (тріщин) самої деталі. Проте, проблема нанесення косого рифлення на деталі із Ті-сплавів значно спрощуються при застосуванні методів електроерозійної обробки (EЕО), які ведуться в рідкому електроліті [45-49]. В цьому випадку, Ті-сплави мають хорошу обробляємість (на рівні твердих сплавів), перевищуючі обробляємість нікелю, міді, латуні, алюмінію, магнію та

\footnotetext{
${ }^{4}$ Відомо, що рівень багатофункціональності в багатьох випадках є одним із основних показників системи, в т.ч., як чинник підвищення iï адаптивності.

${ }^{5}$ Такий склад дозволяє підвищити рівень багатофункціональності системи.
} 
інших невисокої твердості пластичних матеріалів. При цьому слід зазначити, що Ті-сплави на сьогодні мають помітне поширене застосування в авіації та ракетно-космічній техніці, як першорядні конструкційні матеріали. Тому, за сукупністю конструктивнотехнологічних характеристик, призначенням, міцності на розтяження, зрізу (зминання), жорсткості, твердості та помірної питомої ваги, а також корозійної стійкості, корпус ВЗ в корисній моделі виконується із пруткового Ті-сплаву саме типу ВТ6 з анодно-оксидним покриттям [33].

Значна твердість матеріалу корпусу в запропонованій ВЗ конче потрібна в таких трьох технологічних напрямках: для можливості застосування EEO, а також використання корпуса в якості технологічних інструментів (роздача деформуємої втулки та нанесення рифлень на сердечник).

Звідсіля в запропонованій ВЗ, як одправний момент, витікає, що при обгрунтованому виборі найбільш прийнятних матеріалів для сердечника, слід спиратися на такі чинники: матеріал та геометричні характеристики корпуса, а також забезпечення взаємодії з деформуючою втулкою та сердечником в процесі утворення з'єднання, передусім, «ВП+ВП».

Ясно, що при виборі матеріалів для деформуємої втулки пристосування йде до матеріалів корпуса, сердечника та з’єднувального пакета.

Нижче представлений для прикладу найбільш комплекс ймовірних конструкційних матеріалів 3 вибірковим набором характеристик, що необхідно і допустимо пов'язані в КТР запропонованої В3, а саме корпуса (табл. 3), сердечника (табл. 4) та деформуємої втулки (табл. 5). Ті-сплав марки ВТ6

Таблиця 3

Вибіркові механічні характеристики пруткового титанового сплаву ВТ6 [33, 49] (корпус В3)

\begin{tabular}{|l|c|c|c|c|}
\hline \multicolumn{1}{|c|}{ Стан матеріалу } & $\begin{array}{c}\text { Тимчасовий опір } \\
\text { розриву, МПа }\end{array}$ & $\begin{array}{c}\text { Відносне } \\
\text { видовження, \% }\end{array}$ & $\begin{array}{c}\text { Твердість за } \\
\text { Брінеллем, Нв }\end{array}$ & $\begin{array}{c}\text { Міцність на зріз, } \\
\text { МПа }\end{array}$ \\
\cline { 1 - 3 } Відпалений & $900-1100$ & $8-20$ & $255-341$ & $\sim 600$ \\
\hline Загартований і зістарений & $1100-1250$ & $4-6$ & $293-361$ & \\
\hline
\end{tabular}

Таблиця 4

Вибіркові механічні характеристики пруткових матеріалів для сердечника В3 [31, 34, 36, 37]

\begin{tabular}{|c|c|c|c|c|}
\hline Матеріал & $\begin{array}{c}\text { Тимчасовий опір } \\
\text { розриву, МПа }\end{array}$ & $\begin{array}{c}\text { Відносне } \\
\text { видовження, \% }\end{array}$ & $\begin{array}{c}\text { Твердість за } \\
\text { Брінеллем, Нв }\end{array}$ & Стан прутка \\
\hline Алюмінієвий сплав В95 & $530-570$ & 6 & $125-150$ & Високої якості \\
\hline Титановий сплав ВТ1-0 & $355-540$ & $15-20$ & $131-163$ & Підвищеної якості \\
\hline $\begin{array}{c}\text { Корозійностійка сталь 12Х18 } \\
\text { Н9Т }\end{array}$ & $540-880$ & 20 & 170 & $\begin{array}{c}\text { Пруток } \\
\text { нагартований }\end{array}$ \\
\hline $\begin{array}{c}\text { Монеловий сплав марки } \\
\text { НМЖруток }\end{array}$ & 18 & 21 & Пруолоднокатаний (D) \\
\hline
\end{tabular}

Таблиця 5

Вибіркові характеристики заготовки для деформуємої втулки В3 [32, 36, 38, 41, 47]

\begin{tabular}{|c|c|c|c|c|}
\hline \multirow{2}{*}{ Матеріали заготовки } & \multicolumn{2}{|c|}{ Механічні характеристики } & \multicolumn{2}{|c|}{ Технологічні характеристики } \\
\cline { 2 - 5 } & $\begin{array}{c}\text { Тимчасовий опір } \\
\text { розриву, МПа }\end{array}$ & $\begin{array}{c}\text { Відносне } \\
\text { видовження, \% }\end{array}$ & $\begin{array}{c}\text { Відносна товщина } \\
\text { втулки, } \boldsymbol{s}\end{array}$ & $\begin{array}{c}\text { Коефіцієнт } \\
\text { роздачі, } \boldsymbol{\kappa} \boldsymbol{p}^{*}\end{array}$ \\
\hline $\begin{array}{c}\text { Корозійностійка сталь } \\
\text { 12Х18 Н9Т }\end{array}$ & $540-880$ & 20 & $\geq 0,8$ & 1,36 \\
\hline Титановий сплав ВТ1-00 & $265 ?-440$ & $24-25$ & $\geq 0,8$ & 1,3 \\
\hline Дюраль Д18П & 300 & $24-25 ?$ & $\geq 0,8$ & $>1,3$ \\
\hline $\begin{array}{c}\text { Монеловий сплав марки } \\
\text { НМЖМ }\end{array}$ & 440 & 35 & $\geq 0,8$ & $>1,3$ \\
\hline Твердий (Г)** & 490 & 20 & $\geq 0,8$ & $>$ \\
\hline
\end{tabular}

* Допустимі попередні значення

** Г- гарячекатаний 
представлений у двох станах: відпалений (рос. отожженный) та загартований і зістарений.

Матеріали сердечника підібраний таким чином, що мають не тільки допустиму контактну сполучуваність з ТІ-сплавами (корпус), але в порівнянні зі сплавом ВТ6 приблизно в 1,7-2 рази меншу твердість для можливості одержання чіткої рифленої поверхні сердечника при достатній загальній його міцності, уникаючи передчасний відрив технологічного хвостовика.

Матеріали деформуємої втулки мають одночасно не тільки допустиму сполучуваність з ТІ-сплавами і з матеріалами сердечника та з'єднувального пакета, високу пластичність та міцність, а також найбільший серед інших матеріалів, коефіцієнт роздачі втулки, який сягає попередніх значень $\kappa p=1,3-1,4$. При цьому вказана втулка при робочому ході сердечника майже впродовж початкової, а саме пружної деформації роздачі практично не контактує з поверхнею з'єднувального пакета.

Наприклад, в трискладовій В3 з запірним сердечником: корпус - титановий сплав ВТ6; сердечник - корозійностійка сталь 1Х18Н9Т, деформуєма втулка - монеловий м'який (D) сплав (умовне позначення $\mathrm{Ti} \psi \mathrm{Sta} / \mathrm{Mo})$.

На рис. 1 зображено складальне креслення В3 перед поставленням в з'єднувальний пакет; на рис. 2 показана верхня частина корпуса 3 конічною 17 та увігнутою 18 ділянками; на рис. 3 - загальний вид

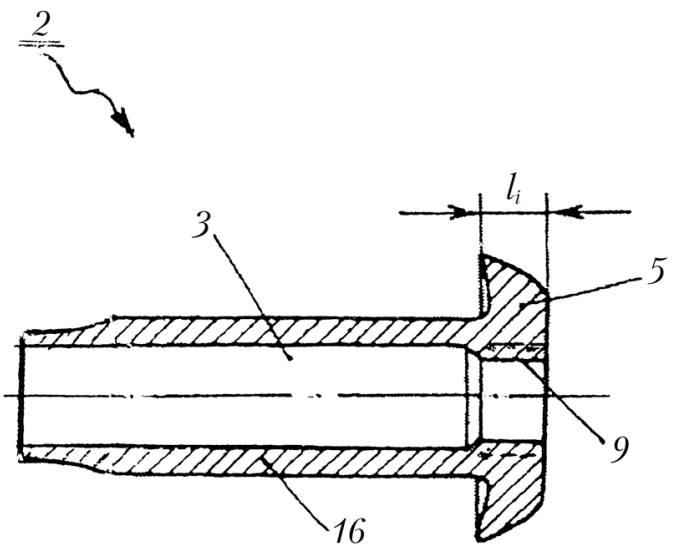

Рис. 3. Корпус ВЗ (кінцева ділянка на рис. 2)

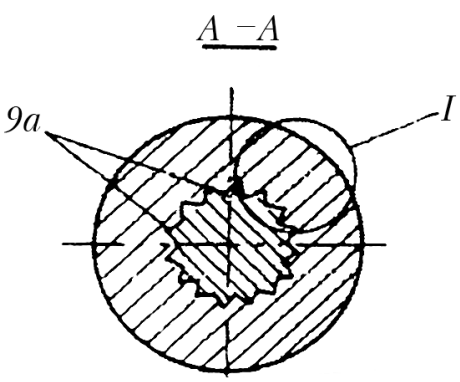

Рис. 5. Переріз А - А на рис. 4 корпуса В3 ( $d_{k}-$ діаметр корпуса) зі ступінчастим отвором; на рис. 4 - поперечний переріз В3 після з'єднання пакета; На рис. 5 - переріз $A-A$ на рис. 4; На рис. $6-$ вузол $I$ на рис. 5 ; на рис. $7-$ креслення для представлення можливого підходу при виготовленні косого рифлення в корпусі В3; на рис. 8 - двополюсник та його полюсний граф; на рис. 9 - укрупнена багаторівнева схема взаємодії елементів ВЗ при клепці пакета листових ПКМ.

Витяжна заклепка для з'єднання переважно композитних деталей $(1+14)$ містить пустотілий циліндричний корпус 2 з осьовим отвором 3 та монтажно-вхідною фаскою 4 на зовнішній поверхні 3 одного боку та закладною головкою 5 з іншого. Вхідна фаска 4 має конічну 17 та увігнуту 18 ділянки. Конічна ділянка може мати, як приклад, кут конусу $\alpha$ на рівні $6-10^{\circ}$, переважно для мілких кріплень з малими товщинами стінок корпуса.

Отвір 3 в зоні закладної головки 5 має внутрішній уступ 9 з косим поверхневим рифленням $9 a 3$ вільним виходом на ㄲï торець. Це рифлення утворює контрувальну ділянку для запирання сердечника 6 в прикінцевій зоні з можливою при необхідності мілкою (до 0,1 мм) проточкою (показана пунктиром). Зазначені вище параметри рифлення (див. рис. 5, 6) виконані на основі стандарту [29], при цьому кут нахилу ліній зубців косого рифлення $9 a$ до твірної циліндра попередньо складає 5-10. Практично точна довжина контрувальної

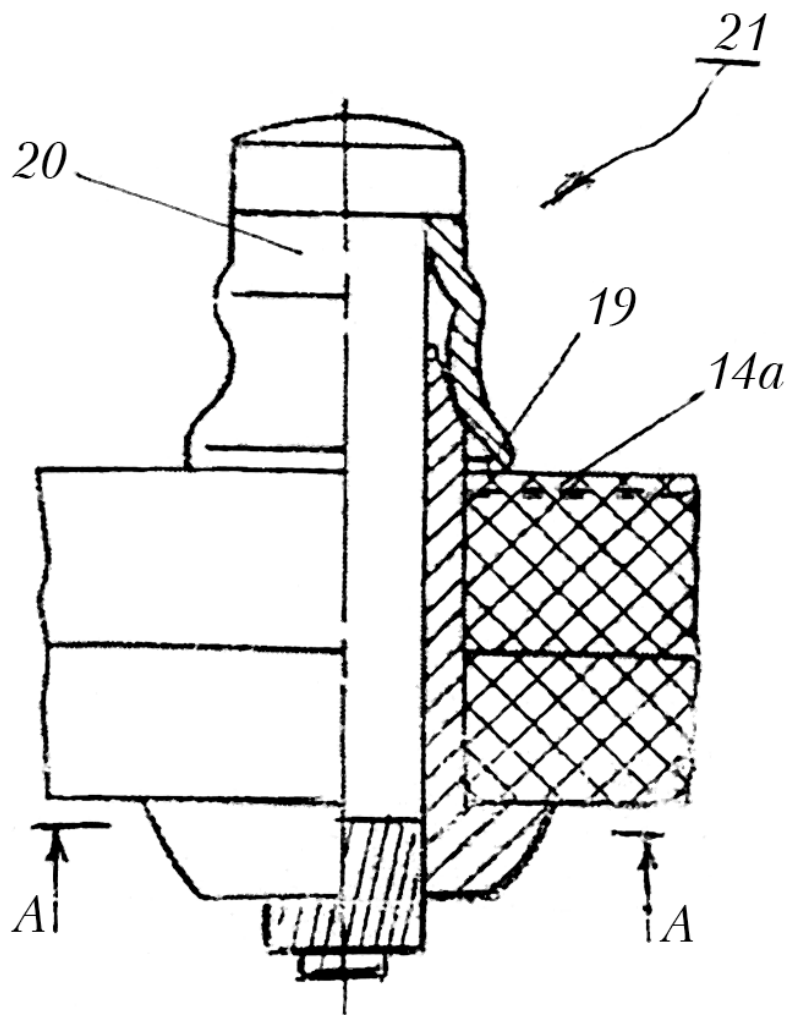

Рис. 4. ВЗ після поставлення та утворення заклепочного з'єднання 


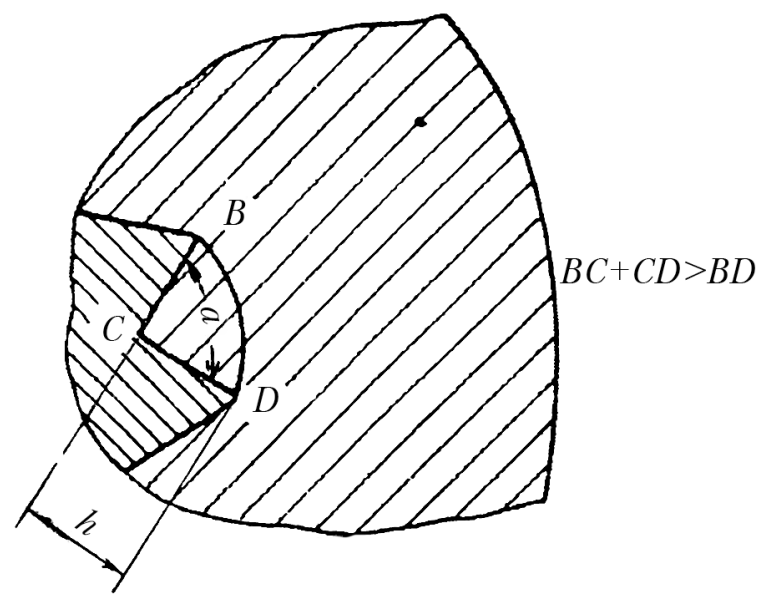

Рис. 6. Вузол I на рис. 5

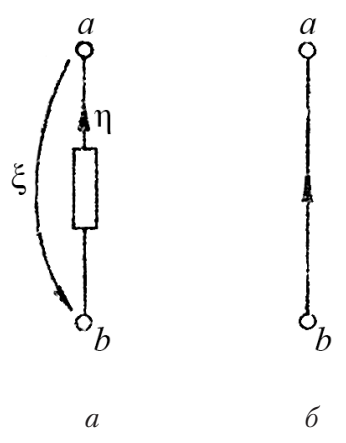

Pис. 8. Двополюсник ( $a$ ) та його полюсний граф (б)

ділянки заклепки визначається експериментально в залежності від ряду факторів, а в першому наближенні вона на рівні товщини $(t)$ закладної головки 5, або ж більше за неї, переходячи, як продовження головки в циліндричну частину корпуса В3.

В отвір 3 з натягом вставлений металевий циліндричний сердечник 6, що має головку 7 на одному кінці та технологічний хвостовик 8 з обривною шийкою $8 a$ (показано спрощено, умовно), упорною шайбою $15^{6}$ та накаткою 10 на другому. При втягуванні сердечника зубці $9 a$ рифлення 9 корпуса проникають в поверхню прикінцевої ділянки $6 a$, що забезпечує їх нероз'ємне механічне з'єднання між собою.

На робочій частині сердечника 6 між головкою 7 i монтажно-вхідною фаскою 4 корпуса 2 розташована деформуєма методом роздачі [38-42, 49] циліндрична двоступінчаста втулка 13. Перша ступінь в ній центруючий циліндричний поясок з товщиною стінки рівній товщині стінки 16 корпуса 2. Друга ступінь дещо стоншений циліндрик 3 внутрішньою фаскою 11, що саме і підлягає роздачі при переміщенні через конічну ділянку 17 з плавним переходом в увігнуту

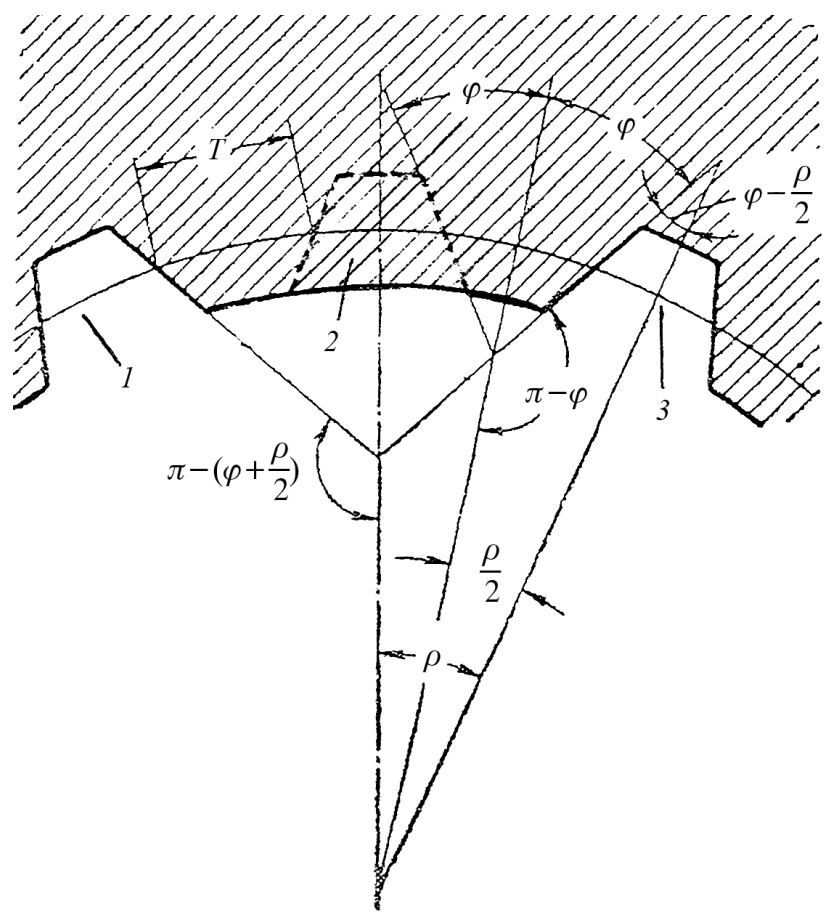

Рис. 7. Утворення мілких внутрішніх трикутових шліців (зубців) в варіанті «через один»

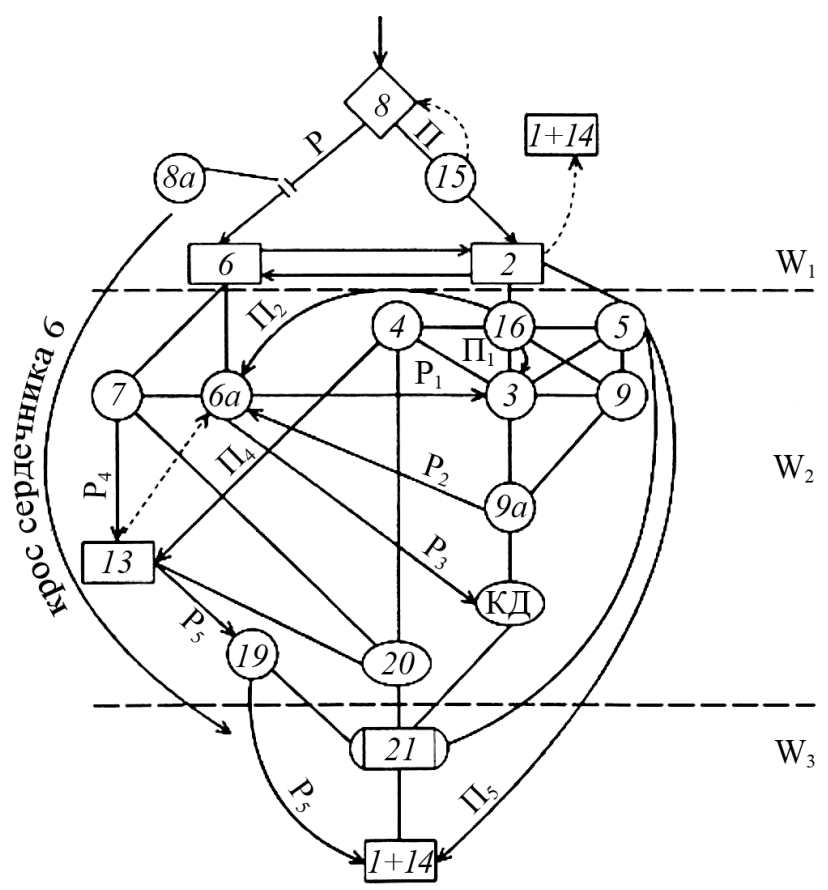

Рис. 9. Укрупнена багаторівнева схема взаємодії елементів В3 при клепці пакета листових ПКМ

ділянку 18. При з'єднанні циліндрична втулка 13 внаслідок роздачі, своїм загнутим сплющеновидним краєм 19 підпирає поверхню композитного пакета 14.

${ }^{6}$ Шайба 15 від спеціального постановочного інструмента, передаючого зусилля, забезпечує належне опорне діяння на закладну головку 5 , яку в системі з рухомим силовим діянням сердечника 6 , можна образно представити,як опорну підошву. 
Тут виникає питання допустимого виокремленого поєднання пари «втулка-пакет». На початку було зазначено, що щільність струму гальванічної пари має бути на рівні $J<5 \mathrm{~mA} / \mathrm{cm}^{2}$ (табл. 1), при відхиленні від цієї вимоги повинні бути прийняті запобіжні міри, найперше, напресування захисного матеріалу, передусім, шару склопластика $14 a$. Якщо ж існують, наприклад,місцеві бокові підходи до ВЗ, то можливе використання проміжної шайби 12.

Ці шайби можуть бути пласкими, або ж у вигляді усіченого кругового конуса, поверхня якого може стати продовженням формуючої поверхні 18.

Практично синхронно з деформуванням втулки 13 відбувається нанесення рифлення на сердечник 6 з вільним виходом на його торець.

При втягуванні з натягом сердечника 6 в отвір 3 корпуса 2, метал сердечника заповнює пази рифлень уступа 9, забезпечуючи цим зчеплення корпуса 3 сердечником. Після утворення замикаючої головки 20 відбувається відрив технологічного хвостовика 8 по шийці $8 a$ і закінчене утворення заклепочного з'єднання 21.

Початкове виконання контрувальної ділянки саме в корпусі 2 не тільки підвищує надійність заклепочного з'єднання, перешкоджаючи виповзанню сердечника при осьовому навантаженні, але також підвищує його міцність при втягуванні в корпус.

Протидію осьовим навантаженням видавлювання чинять сили сухого тертя зворотнього знаку напрямку з необхідністю при цьому здійснення обертового руху сердечника в корпусі. Тобто, сердечник знаходячись в «стиснутому» стані, повинен подолати під дією осьового навантаження сили тертя а, водночас, і супротив від здійснення розвороту по куту нахилу зубців. Тут з'єднання працює за принципом «тугої» різьби [25]. За рахунок рифлення збільшується площа контакту взаємодіючих частин корпуса і сердечника. Поперечний переріз рифлення контрувальної ділянки має вигляд «зірочки» (рис. 5). При цьому в порівнянні з гладкою поверхнею корпуса, площа контакту, а відповідно і тертя збільшується в півтора рази. В трикутнику $B C D$ довжина $B C+C D>B D$ (рис. 6).

Результати експериментальних досліджень з'єднання типу «рифлення» були приведені вище.

Водночас, утворення косого рифлення на внутрішній поверхні циліндра малого діаметра потребує врахування переваг та недоліків не тільки при вибоpi методу виготовлення (протягування, або ж електроерозійна обробка), але і стосовно структури самої операції по оптимальній кількості переходів в ній.

Приклад 1. Відомо, що механічна обробка деталей із ТІ-сплавів, в тому числі протягування мілких внутрішніх трикутових шліців звичайними протяжками суттєво утруднена із-за високого відношення границі текучості до границі міцності, відносно низькою теплопровідністю, налипанням титану на інструмент та ін. Особливо небезпечним недоліком можна визначити впливання водню із атмосфери у вигляді проникнення газу в структуру поверхневого шару і хімічну взаємодію з титаном, що в кінцевому результаті призводить до утворення тріщин $[43-46,49]$. Також труднощі при протягуванні викликані і тим, що товщина $T$ шліца (рис. 7) в деталі, що обробляється, може бути дуже малою менше одного міліметра, оскільки ж товщина шліца деталі відповідає ширині впадин між зубцями шліцепрорізної протяжки, то радіус округлення у впадині необхідно робити менше 0,05 мм, але це забезпечити вкрай складно.

Проте, вказаний процес можна спростити, коли протяжка складається з двох секцій. Перша секція обробляє половину шліців, а саме через один (впадини $1,3,5 . .$.$) . Друга секція обробляє другу частину$ шліців (впадини 2, 4, 6...). Обидві секції протяжки рівнозначні, однак при виготовленні зрушені один щодо одного на кут $\rho$ (рис. 7).

Приклад 2. Вказані вище труднощі механічної обробки можна обійти при застосуванні EЕО. Поперше, електроерозійна обробка є відмінним варіантом тому, що обробка ведеться в рідкому діелектрику, де доступ газів атмосфери в зоні обробки значно утруднений. Тому більшість операцій при ЕЕО проводять в рідкому середовищі [45-49]. Подруге, якщо прийняти електроерозійну обробляємість сталі за одиницю, то для інших металів вона може бути представлена в таких відносних одиницях: вольфрам $-0,3$; твердий сплав $-0,5$; титан 0,6 ; нікель $-0,8$; мідь $-1,1$; латунь $-1,6$; алюміній -4 ; магній -6 .

Застосування ЕЕО-методу найбільш поширене при обробці малогабаритних і навіть мініатюрних виробів, які мають різні фасонні прорізи і канавки та інші елементи складних конфігурацій [45-49].

\section{2. Формалізований виклад (схемна модель)}

Як відомо [49, 52] графи широко використовуються, як структурні моделі фізичних систем, допускаючих ідеалізоване уявлення у вигляді схем зі зосередженими компонентами. При цьому схема 3 двополюсними компонентами, незалежно від їх конкретної фізичної природи може бути представлена полюсним графом (рис. 8). Тому, при складанні багатозв'язної та багаторівневої укрупненої В3-схеми (рис. 9), було залучено ряд положень із основних понять теорії неорієнтованих та полюсних графів [49-52 та ін.]. При цьому, для любого двополюсника (рис. $8, a$ ) полюсним графом служить дуга 3 двома кінцевими вершинами (рис. 8, б). В загальному випадку рівняння двополюсника $(\eta, \xi)=0$ містить дві змінних $\eta$ i $\xi$. Оскільки із двох змінних $\eta \mathrm{i} \xi$ одна характеризує подіяння (рос. воздействие), тобто стан двополюсника відносно його плюсів, а друга - реакцію, то їх позитивні направлення вважають взаємопротилежними. 
В статті (рис. 9) вибраний варіант зі спрощеним процесним підходом до складання схемної моделі, де $\mathrm{P}_{i}$ - дугами відображено зв'язок компонента (підвузол, деталь, елемент деталі) ВЗ-схеми із функцією силового подіяння, в т.ч. як інструмента, на інший компонент зі зміною початкового стану того в процесі утворення В3, а $\Pi_{i}-$ дугами зв'язок між компонентами опору. По-перше, з функцією лише опорного подіяння на вищезазначений компонент зі зміненим станом в тому ж процесі, а подруге, опір тертя (взаємне зміщення деталей). Із схеми на рис. 9, виходить, що в ній наявні дво- , а також багатополюсники. В останньому мова йде про компоненти, що мають $m+1$ полюсів, за допомогою яких вони можуь об'єднуватись 3 іншими компонентами [50]. Наприклад, це триполюсними $6 a$ та 13 з числом входів - 2. Нижче, це питання більш деталізоване.

На рис. 9 мають місце такі умовні позначення:

- чотирикутник - деталі (металеві чи композитні);

- кружок - виділені в схемі елементи деталі ( як єдиного цілого об'єкта);

- овальний кружок - елементи окремих деталей в з’єднанні (підвузол);

- прямокутник з додатковим округленням торців (21) - заклепка в з'єднанні з пакетом ПКМ;

- ребра (неорієнтовані відрізки) - нерозривний конструктивний зв'язок між задіяними в процесі елементами деталей, при цьому як в самій деталі, так і у вузлових компонентах В3 (це сильно пов'язані між собою складові).

- дуги (орієнтовані відрізки). По-перше, це номенклатура активних технологічних дій $\mathrm{P}_{i}$ в кросі сердечника, а саме:

$\mathrm{P}_{1}$ - початковий рух під дією силового тягового вузла $з$ поставленням сердечника 3 натягом в отворі корпуса;

$\mathrm{P}_{2}$ - нанесення рифлення на сердечник;

$\mathrm{P}_{3}$ - утворення внутрішньої контрувальної ділянки (КД);

$\mathrm{P}_{4}-$ роздача втулки;

$\mathrm{P}_{5}$ - взаємодія (натиснення) втулки 3 поверхнею обшивки 1 композитного пакета;

По-друге, $\Pi_{i}$ - це комплекс різновидів опорних підтримуючих натиснень (рос. воздействий) та опорний супротив тертю, для відповідного забезпечення активних дій $\mathrm{P}_{i}$ в технологічному процесі.

- Переривчасті дуги - показ місця розташування зазначеної деталі в конструкції В3, або безпосередньо в з'єднувальному пакеті (конструктивнотехнологічний зв'язок).

- $\mathrm{W}_{i}$ - рівні розбиття ВЗ-схеми.

При цьому, слід зазначити, що можна в загальному розглядати активні дії зі знаком плюс, а опорні підтримання зі знаком мінус. Тоді можна вважати, що алгебраїчна сума активних і підтримуючих дій дорівнює нулю.

\section{Висновки}

1. Пропонується підвищеної надійності та технологічності металева витяжна заклепка для використання в авіабудування, найперше, для клепки вуглепластикових елементів конструкцій планера в умовах дії вібраційних навантажень.

2. Заклепка складається з корпуса, сердечника та задіяної ними циліндричної втулки, яка будучи в складі замикаючої головки, має в кінці процесу підвищену опорну поверхню при стиску композиційного пакета. В3 також має внутрішню контрувальну ділянку, утвореної з'єднанням рифлених поверхонь сердечника з корпусом, що забезпечує стопоріння сердечника.

3. Виходячи 3 конструктивно-технологічних особливостей заклепки та з урахуванням високої корозійної дії вуглепластика, рекомендовано застосовувати корпус ВЗ, як ключового багатофункціонального елемента в складі В3, насамперед, із сплаву ВТ6 (першорядний приклад).

4. Представлена укрупнена схемна модель В3 (процесний підхід) з урахуванням конструктивнотехнологічних особливостей кріплення.

\section{Абревіатури та умовні позначення}

ЛА - літальний апарат;

АT - авіаційна техніка;

КТС - конструктивно-технологічна схема;

КТР - конструктивно-технологічні рішення;

КСОП - кріпильні системи однобічного поставлення;

В3 - витяжна заклепка;

ЗзЗС - заклепка з запірним сердечником;

ЗКГ - закладна головка заклепки;

ЗМГ - замикаюча головка заклепки;

КД - контрувальна ділянка;

MC - металеві сплави;

ПКМ - полімерні композиційні матеріали;

ВП - вуглепластик;

EЕО - електроерозійна обробка;

$\mathrm{P}_{i} \quad$ - послідовні активні дії при ході (кросі) сердечника, насамперед, забезпечення стиску пакета, утворення КД та сформування ЗМГ;

$\Pi_{i} \quad$ - дія опорних сил ( в умовах двобічного натиснення);

Кр - коефіцієнт роздачі циліндричної втулки;

J - - показник щільності струму корозії

\section{Література}

[1] Кива Д.С., Забашта В.Ф. Фюзеляжные секции гражданских самолетов из полимерных композиционных материалов (конструктивно-технологические аспекты) // Технологические системы.2018, №1, c. $37-63$. 
[2] Ківа Д.С., Забашта В.Ф. Композитний кесон крила транспортних літаків (конструктивно-технологічні аспекти) // Технологические системы. 2018, №3, с.7-31.

[3] Патент України № 131809 кл. В64С 3/26 В29С 43/64.

[4] Каблов Е.Н., Каримова С.А. и др. Коррозионная активность углепластиков и защита металлических силовых конструкций в контакте с углепластиком // Коррозия, материалы, защита. 2011, №12.

[5] Руководство по защите от коррозии самолёта ЯК-40 в эксплуатации (Рэ-4) - М.: 2000 // Электронный pecypc: www.aviadocs.net/rie/Yak40/CD1/RTYE/YAK40RYE-4pdf.

[6] ГОСТ 15150-69. Машины, приборы и другие технические изделия. Исполнения для различных климатических районов.

[7] ГОСТ 9.005-72. Допустимые и недопустимые контакты с неметаллами.

[8] ГОСТ 24627-81. Самолёты и вертолеты, общие требования. Приспособление конструкций к защите от коррозии, старения и биоповреждения.

[9] Семеничев В.В., Смирнова Т.В. Оценка коррозионной стойкости защитных и функциональных покрытий с помощью измерения скорости коррозии// Труды ВИАМ, 2016.

[10] Матис В.Г., Поплавский В.В. Устойчивость алюминия и его сплавов к контактной коррозии в гальванопарах со сталями с металлическими покрытиями// Труды БГТУ, 2015, №3.

[11] Кривов Г.А., Бычков С.А. и др. Технологическое проектирование сборных частей планера самолетов из полимерных композиционных материалов // Технологические системы.2014, №1, с.23-30.

[12] Матвиенко В.А., Качмар Р.В. и др. Крепежные системы для авиационных конструкций, подтверженных вибрационным нагрузкам. // Технологические системы. 2018, №3, с.32-36.

[13] Вашуков Ю.А., Перепелкин В.А. и др. Конечно-элементное моделирование напряженного состояния при подкреплении отверстий в элементах из полимерных композиционных материалов // Известия Самарского научного центра РАН.2005, т.7, №2, c. $436-441$.

[14] Лехницкий С.Г. Теория упругости анизотропного тела: -М.; Наука, 1977, 415 с.

[15] Савин Г.Н., Тульчий В.И. Пластинки, подкрепленные составными кольцами и упругими накладками - К.: Наукова Думка.1977.

[16] Сёмин М.И. Болтовые и заклёпочные соединения из композиционных материалов Машиностроение, 1989, 44c.

[17] Григорьев В.П., Голдовский Т.Б., Клёпка конструкций из лёгких сплавов - М.: Оборонгиз, 1954, 348c.

[18] ГОСТ-Р ИСО 15973-2005. Заклёпки «слепые» с закрытыми концами, разрывающиеся втягиванием сердечника и выступающей головкой (корпус из алюминиевых сплавов и стальной сердечник) - M.: 2006, 9 c.
[19] ОСТ 1.00656-81. Заклёпки с сердечником. Технические условия.

[20] ОСТ 1. 39502-77. Стопорение болтов, винтов, шпилек, штифтов и гаек.

[21] Авторское свидетельство СССР № 1490328, кл. F16B 19/10, 1989.

[22] Авторское свидетельство СССР № 1760195 А1, кл. F16B, 19/08, 1991.

[23] Патент США №4457655, кл. F16B 19/10, 1984.

[24] Патент России №2394174 C1, кл. F16B/08, 2010.

[25] Патент России №2006692 C1, кл. F16B 19/10, 1984.

[26] Патент России №2134364 C1, кл. F16B 19/06, 1999.

[27] Патент России №2582472 C1, кл. F16B 19/06, 2016.

[28] Заявка и 201905287, 20.05.2019

[29] ГОСТ 21474-75. Рифления прямые и сетчатые. Форма и основные размеры.

[30] Рифления /https.//www.optprommrtif.ru/catalog/ stati-kataloga/riflenie.ptp

[31] ГОСТ 26442-85 Титан технический ВТ1-0.

[32] ГОСТ 19907-91 Титановый сплав ВТ1-00.

[33] ГОСТ 26492-85 Прутки повышенного качества из титана ВТ6.

[34] ГОСТ 18907-73 Сталь 12Х18Н9Т (старое Х18Н9Т). Прутки нагартованные.

[35] ГОСТ 14838-78 Проволока из алюминиевых сплавов для холодной высадки.

[36] Арчакова 3.Н. и др. Структура и свойства полуфабрикатов из алюминиевых сплавов - М.: Металлургия. $1984,408 \mathrm{c}$.

[37] ГОСТ 1525-91. Прутки из сплавов монеля. Технические условия.

[38] Драчёв В.В. Технология листовой штамповки// Электронный ресурс //https:studfiles.net/preview $/ 417$

[39] Константинов В.Л. Кузнечно-штамповочное производство - М.: НИЦ, 2014, 464 с.

[40] Аверкиев Ю.А., Аверкиев А.Ю. Технология листовой штамповки - М.: Машиностроение, 1981, 201 с.

[41] Зубцов. М.Е. Листовая штамповка - Л.: Машиностроение, 1980, 481 с.

[42] Романовский В.Л. Справочник по холодной штамповке - М.: Машиностроение 1974, 520 с.

[43] Хорбенко И.Г. Ультразвук в машиностроении - М.: Машиностроение, 1974, 280 с.

[44] Балюра П.Г. Протягивание пазов - М.: Машиностроение, 1964, $171 \mathrm{c}$.

[45] Электроэрозионная обработка. Описание процесса, принципы установки электроэрозионной обработки// Электронный ресурс www.eti/su/articles/electrotechnika1887.html.

[46] Елисеев Ю.С. и др. Электроэрозионная обработка изделий авиационно-космической техники - М.: МГТУ, 2010, 437 с.

[47] Оглезнев Н.Д., Абляз Т.Р. Влияние режимов электроэрозионной прошивки стали $40 \mathrm{X}$ на микроструктуру и точность размеров отверстий // Современные проблемы науки и образования, 2014, №2. 
[48] Забельман Д.М. Скоростное электроэрозионная обработка пазов системы охлаждения жаровой трубы камеры сгорания// Металлообработка, 2012.

[49] Информация интернет-изданий.

[50] Сигорский В.П. Математический аппарат инженера - К.: Техніка, 1975, 768 с.
[51] Гавриш А.П., Ефремов А.И. Автоматизация технологической подготовки машиностроительного производства. - М.: Техніка, 1982, 215 с.

[52] Майнека Э. Алгоритмы оптимизации на сетях и графах. - М.: Мир, 1981, 323 с.

\section{Zabashta V.F.}

Ukrainian Research Institute of Aviation technology, JCS. Ukraine, Kyiv

\section{TO THE PROBLEM ADVANCED AIRCRAFT STRUCTURE COMPONENT COUPLINES MADE OF POLYMER COMPOSITES}

A method of airframe component couplings made of polymer composites (predominantly carbon fiber) is proposed in the paper. Analogs of structure and technological features of the fastening systems for joints of composite elements with limited access (on side access) were analyzed. In cutting it composite buckling blind fastener comprises a fastener body, a stem, cylindrical sleeve and interlock (without locking ring).

Rivet material selection implemented taking account the level of corrosion current density. A formalized structural and technological scheme the logical structure of this blind fastener is proposed. [dx.doi.org/10.29010/88.5]

Keywords : composite; carbon - reinforced plastic; blind fastener; fastener body; stem; sleeve; interlock; wavy surface; rivet connection; formalized scheme.

\section{References}

[1] Kiva D.S., Zabashta V.F. Fyuzelyajnye sekcii grajdanskih samoletov iz polimernyh kompozicionnyh materialov (konstruktivno-tehnologicheskie aspekty) // Tehnologicheskie sistemy.2018, №1, s.37 - 63.

[2] Kiva D.S., Zabashta V.F. Kompozitnii keson krila transportnyh litakiv (konstruktivno-tehnologichni aspekty) // Tehnologicheskie sistemy. 2018, №3, s.7 - 31 .

[3] Patent Ukrainy № 131809 kl. V64S 3/26 V29S 43/64.

[4] Kablov E.N., Karimova S.A. i dr. Korrozionnaya aktivnost' ugleplastikov i zaschita metallicheskih silovyh konstrukcii v kontakte s ugleplastikom // Korroziya, materialy, zaschita. 2011, №12.

[5] Rukovodstvo po zaschite ot korrozii samolyota YAK-40 v ekspluatacii (Re-4) - M.: 2000 // Elektronnyi resurs: www.aviadocs.net/rie/Yak-40/CD1/RTYE/YAK40RYE-4pdf.

[6] GOST 15150-69. Mashiny, pribory i drugie tehnicheskie izdeliya. Ispolneniya dlya razlichnyh klimaticheskih raionov.

[7] GOST 9.005-72. Dopustimye i nedopustimye kontakty s nemetallami.

[8] GOST 24627-81. Samolyoty i vertolety, obschie trebovaniya. Prisposoblenie konstrukcii k zaschite ot korrozii, stareniya i biopovrejdeniya.

[9] Semenichev V.V., Smirnova T.V. Ocenka korrozionnoi stoikosti zaschitnyh i funkcional'nyh pokrytii s pomosch'yu izmereniya skorosti korrozii// Trudy VIAM, 2016.

[10] Matis V.G., Poplavskii V.V. Ustoichivost' alyuminiya i ego splavov k kontaktnoi korrozii v gal'vanoparah so stalyami s metallicheskimi pokrytiyami// Trudy BGTU, 2015, №3.

[11] Krivov G.A., Bychkov S.A. i dr. Tehnologicheskoe proektirovanie sbornyh chastei planera samoletov iz polimernyh kompozicionnyh materialov // Tehnologicheskie sistemy.2014, №1, s.23-30.

[12] Matvienko V.A., Kachmar R.V. i dr. Krepejnye sistemy dlya aviacionnyh konstrukcii, podtverjennyh vibracionnym nagruzkam. // Tehnologicheskie sistemy. 2018, №3, s.32-36.

[13] Vashukov YU.A., Perepelkin V.A. i dr. Konechno-elementnoe modelirovanie napryajennogo sostoyaniya pri podkreplenii otverstii v elementah iz polimernyh kompozicionnyh materialov // Izvestiya Samarskogo nauchnogo centra RAN.2005, t.7, №2, s.436 - 441 .

[14] Lehnickii S.G. Teoriya uprugosti anizotropnogo tela: -M.; Nauka, 1977, 415 s.

[15] Savin G.N., Tul'chii V.I. Plastinki, podkreplennye sostavnymi kol'cami i uprugimi nakladkami - K.: Naukova Dumka.1977. 
[16] Syomin M.I. Boltovye i zaklyopochnye soedineniya iz kompozicionnyh materialov - M.: Mashinostroenie, 1989, 44s.

[17] Grigor'ev V.P., Goldovskii T.B., Klyopka konstrukcii iz lyogkih splavov - M.: Oborongiz, 1954, 348s.

[18] GOST-R ISO 15973-2005. Zaklyopki slepye s zakrytymi koncami, razryvayuschiesya vtyagivaniem serdechnika i vystupayuschei golovkoi (korpus iz alyuminievyh splavov i stal'noi serdechnik) - M.: 2006, 9 s.

[19] OST 1.00656-81. Zaklyopki s serdechnikom. Tehnicheskie usloviya.

[20] OST 1. 39502-77. Stoporenie boltov, vintov, shpilek, shtiftov i gaek.

[21] Avtorskoe svidetel'stvo SSSR № 1490328, kl. F16B 19/10, 1989.

[22] Avtorskoe svidetel'stvo SSSR № 1760195 A1, kl. F16B, 19/08, 1991.

[23] Patent SSHA №4457655, kl. F16B 19/10, 1984.

[24] Patent Rossii №2394174 S1, kl. F16B/08, 2010.

[25] Patent Rossii №2006692 S1, kl. F16B 19/10, 1984.

[26] Patent Rossii №2134364 S1, kl. F16B 19/06, 1999.

[27] Patent Rossii №2582472 S1, kl. F16B 19/06, 2016.

[28] Zayavka i 201905287, 20.05.2019

[29] GOST 21474-75. Rifleniya pryamye i setchatye. Forma i osnovnye razmery.

[30] Rifleniya /https.//www.optprommrtif.ru/catalog/stati-kataloga/riflenie.ptp

[31] GOST 26442-85 Titan tehnicheskii VT1-0.

[32] GOST 19907-91 Titanovyi splav VT1-00.

[33] GOST 26492-85 Prutki povyshennogo kachestva iz titana VT6.

[34] GOST 18907-73 Stal' 12H18N9T (staroe H18N9T). Prutki nagartovannye.

[35] GOST 14838-78 Provoloka iz alyuminievyh splavov dlya holodnoi vysadki.

[36] Archakova Z.N. i dr. Struktura i svoistva polufabrikatov iz alyuminievyh splavov - M.: Metallurgiya. 1984,408 s.

[37] GOST 1525-91. Prutki iz splavov monelya. Tehnicheskie usloviya.

[38] Drachyov V.V. Tehnologiya listovoi shtampovki// Elektronnyi resurs //https:studfiles.net/preview/417

[39] Konstantinov V.L. Kuznechno-shtampovochnoe proizvodstvo - M.: NIC, 2014, 464 s.

[40] Averkiev YU.A., Averkiev A.YU. Tehnologiya listovoi shtampovki - M.: Mashinostroenie, 1981, $201 \mathrm{s.}$

[41] Zubcov. M.E. Listovaya shtampovka - L.: Mashinostroenie, 1980, $481 \mathrm{~s}$.

[42] Romanovskii V.L. Spravochnik po holodnoi shtampovke - M.: Mashinostroenie 1974, $520 \mathrm{~s}$.

[43] Horbenko I.G. Ul'trazvuk v mashinostroenii - M.: Mashinostroenie, 1974, $280 \mathrm{~s}$.

[44] Balyura P.G. Protyagivanie pazov - M.: Mashinostroenie, 1964, $171 \mathrm{s.}$

[45] Elektroerozionnaya obrabotka. Opisanie processa, principy ustanovki elektroerozionnoi obrabotki// Elektronnyi resurs www.eti/su/articles/electrotechnika1887.html.

[46] Eliseev YU.S. i dr. Elektroerozionnaya obrabotka izdelii aviacionno-kosmicheskoi tehniki - M.: MGTU, 2010,437 s.

[47] Ogleznev N.D., Ablyaz T.R. Vliyanie rejimov elektroerozionnoi proshivki stali 40H na mikrostrukturu i tochnost' razmerov otverstii // Sovremennye problemy nauki i obrazovaniya, 2014, №2.

[48] Zabel'man D.M. Skorostnoe elektroerozionnaya obrabotka pazov sistemy ohlajdeniya jarovoi truby kamery sgoraniya// Metalloobrabotka, 2012.

[49] Informaciya internet-izdanii.

[50] Sigorskii V.P. Matematicheskii apparat injenera - K.: Tehnika, 1975, 768 s.

[51] Gavrish A.P., Efremov A.I. Avtomatizaciya tehnologicheskoi podgotovki mashinostroitel'nogo proizvodstva. - M.: Tehnika, 1982, $215 \mathrm{~s}$.

[52] Maineka E. Algoritmy optimizacii na setyah i grafah. - M.: Mir, 1981, $323 \mathrm{s.}$ 